ment, so only one mode of surface plasmon wave can get through. At certain wavelengths of light, the frequency of the surface plasmon wave is close to the frequency of the oscillating electrons within the bulk of the metal. In this case the surface plasmon wave and the oscillating electrons interact in such a way that the direction of travel of the wave's peaks and troughs is reversed, giving negative refraction.

For Dionne, the goal of "peeking round the corner" has been achieved. "It's like alchemy," she says. "But it works."

Others in the field are more cautious. Mark Stockman, a theoretician at Georgia State University in Atlanta, is concerned about the system's inefficiency, pointing out that only about $1 \%$ of the light gets through. Dionne emphasizes that enough light gets through to be detected directly and says she thinks improvements can be made.

And some are unconvinced that it offers true negative refraction. Allan Boardman, a theoretician from the University of Salford, UK, and Vladimir Shalaev from Purdue University in West Lafayette, Indiana, who are also trying to negatively refract visible light, argue that the experiment simply shows negative refraction of plasmons, rather than of light itself. "It's not negative refraction per se," says Boardman. "They've got to qualify it a lot more."

But others such as Nikolay Zheludev of the University of Southampton, UK, say this doesn't really matter, because the end result is the same. "If everything is correct, this is a grand claim," says Zheludev. "Yes, they had negative refraction," agrees metamaterials and plasmonics expert Eli Yablonovitch from the University of California, Los Angeles. "I don't see much controversy there."

Pendry is also convinced, although he says he didn't expect to see the effect demonstrated so soon. "It is very impressive," he says. "They've done it in a most spectacular way."

Whether the approach counts as true negative refraction or not, to do anything useful with it will require turning the two-dimensional system into a three-dimensional device. Atwater envisages stacking a dense array of waveguides on end: "We have not done this yet, but at least this work illustrates the inherent possibility of doing so."

Katharine Sanderson

1. Parazzoli, C. G., Greegor, R. B., Li, K., Koltenbah, B. E. C. \& Tanielian, M. Phys. Rev. Lett. 90,107401 (2003)

2. Houck, A. A., Brock, J. B. \& Chuang, I. L. Phys. Rev. Lett. 90, 137401 (2003).

3. Schurig, D. et al. Science 314, 977-980 (2006).

4. Dolling, G., Wegener, M., Linden, S. \& Hormann, C. Optics Express 14, 1842-1849 (2006).

\title{
PR's 'pit bull' takes on open access
}

The author of Nail 'Em! Confronting High-Profile Attacks on Celebrities and Businesses is not the kind of figure normally associated with the relatively sedate world of scientific publishing. Besides writing the odd novel, Eric Dezenhall has made a name for himself helping companies and celebrities protect their reputations, working for example with Jeffrey Skilling, the former Enron chief now serving a 24-year jail term for fraud.

Although Dezenhall declines to comment on Skilling and his other clients, his firm, Dezenhall Resources, was also reported by Business Week to have used money from oil giant ExxonMobil to criticize the environmental group Greenpeace. "He's the pit bull of public relations," says Kevin McCauley, an editor at the magazine O'Dwyer's PR Report.

Now, Nature has learned, a group of big scientific publishers has hired the pit bull to take on the free-information movement, which campaigns for scientific results to be made freely available. Some traditional journals, which depend on subscription charges, say that open-access journals and public databases of scientific papers such as the National Institutes of Health's (NIH's) PubMed Central, threaten their livelihoods.

From e-mails passed to Nature, it seems Dezenhall spoke to employees from Elsevier, Wiley and the American Chemical Society at a meeting arranged last July by the Association of American Publishers (AAP). A follow-up message in which Dezenhall suggests a strategy for the publishers provides some insight into the approach they are considering taking.

The consultant advised them to focus on simple messages, such as "Public access equals government censorship". He hinted that the publishers should attempt to equate traditional publishing models with peer review, and "paint a picture of what the world would look like without peer-reviewed articles".

Dezenhall also recommended joining forces with groups that may be ideologically opposed to government-mandated projects such as PubMed Central, including organizations that have angered scientists. One suggestion was the Competitive

\section{"Media massaging}

is not the same

as intellectual

debate."

\section{Enterprise Institute, a}

conservative think-tank based in

Washington DC, which has used oil-industry money to promote sceptical views on climate change. Dezenhall estimated his fee for the campaign at $\$ 300,000-500,000$.

In an enthusiastic e-mail sent to colleagues after the meeting, Susan Spilka, Wiley's director of corporate communications, said Dezenhall explained that publishers had acted too defensively on the freeinformation issue and worried too much about making precise statements. Dezenhall noted that if the other side is on the defensive, it doesn't matter if they can discredit your statements, she added: "Media massaging is not the same as intellectual debate."

Officials at the AAP would not comment to Nature on the details of their work with Dezenhall, or the money involved, but acknowledged that they had met him and subsequently contracted his firm to work on the issue.
"We're like any firm under siege," says Barbara Meredith, a vice-president at the organization. "It's common to hire a PR firm when you're under siege." She says the AAP needs to counter messages from groups such as the Public Library of Science (PLoS), an open-access publisher and prominent advocate of free access to information. PLoS's publicity budget stretches to television advertisements produced by North Woods Advertising of Minneapolis, a firm best known for its role in the unexpected election of former professional wrestler Jesse Ventura to the governorship of Minnesota.

The publishers' link with Dezenhall reflects how seriously they are taking recent developments on access to information. Minutes of a 2006 AAP meeting sent to Nature show that particular attention is being paid to PubMed Central. Since 2005, the NIH has asked all researchers that it funds to send copies of accepted papers to the archive, but only a small percentage actually do. Congress is expected to consider a bill later this year that would make submission compulsory.

Brian Crawford, a senior vice-president at the American Chemical Society and a member of the AAP executive chair, says that Dezenhall's suggestions have been refined and that the publishers have not to his knowledge sought to work with the Competitive Enterprise Institute. On the censorship message, he adds: "When any government or funding agency houses and disseminates for public consumption only the work it itself funds, that constitutes a form of selection and self-promotion of that entity's interests." Jim Giles 


\section{Terror fears prompt tighter controls for UK labs}

In the wake of security concerns about terrorist attacks, the UK Home Office boosted its list of 'controlled substances' used in the lab from 47 to 103 on 25 January.

University, hospital and commercial labs will have to give the government details of their exact stocks of all of these substances, which now include the virus that causes African swine fever and the strain of enterohaemorrhagic Escherichia coli that recently caused havoc by contaminating US spinach. If asked, they will also have to inform the police of the names of everyone handling them. The updated list also sees two new categories introduced - 18 animal pathogens and 2 fungi are now included as substances that might be of use to terrorists.

Tony McNulty, minister for police and security, says the measures are to stop terrorist groups using chemical or biological materials as terrorist weapons - a chief threat anticipated by the UK security service MI5. But some scientists say the extended list is overkill, and the increased burden of paperwork will hamper research.

\section{Russia woos India in deal on nuclear fuel}

With the much debated Indo-US nuclear deal still facing roadblocks, Russian President Vladimir Putin has offered to build four more nuclear reactors in India, in addition to the two 1,000-megawatt reactors it is already building at Kudankulam in the south of the country.

Indian officials say Russia has offered them a lifetime fuel supply and will not stop them from reprocessing the spent fuel two crucial issues that have clouded India's deal with Washington. Russian officials say that they are still bound by the guidelines of the Nuclear Suppliers Group; but these may change and, as this regime is voluntary, it may not significantly restrict their actions.

The Indo-Russian accord, signed in New Delhi on 25 January, is seen as a signal that Russia will step in if the US deal falls through.

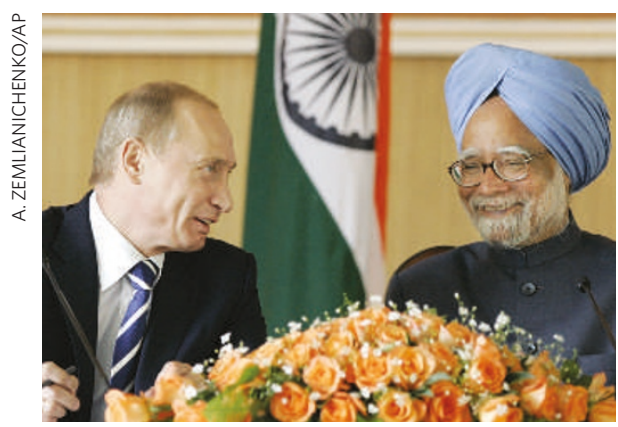

Vladimir Putin and Manmohan Singh discuss Russia's nuclear deal with India.

\section{Fisheries lay plans to save tuna stocks from extinction}

\section{On 26 January, after a five-} day meeting in Kobe, Japan, representatives from the world's tuna fisheries issued an 'action plan' on how to save the beleaguered fish. The group agreed that urgent action was needed and decided on broad strategies, from developing catch documentation and tagging systems, to improving trade-tracking programmes and enforcing strict penalties.

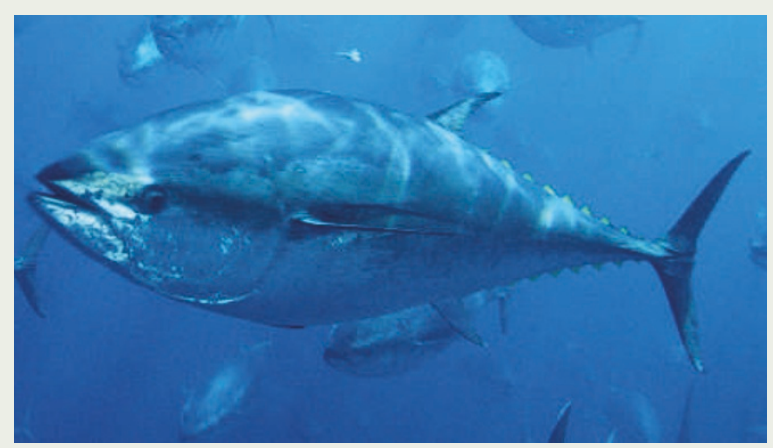

But as yet the plan lacks details such as numerical targets or timelines. "Their only agreement was to gather more data and talk more often," said conservation group the WWF in a press release.

Overfishing of tuna is endangering wild stocks - with some now listed as critically endangered. The number of spawning Atlantic bluefin tuna in the western Atlantic is estimated to be at $13 \%$ of 1975 levels, for example, according to a WWF report. Japan is widely blamed for the decline, as it consumes more than a quarter of the 2-million-tonne global tuna production.

The group plans to meet next in 2009 to work out more specific plans.

\section{US set to embrace law on genetic discrimination}

The US Congress looks likely to ban the use of genetic information in job-hiring and insurance-coverage decisions, after a 12-year effort by lawmakers.

The Genetic Information

Nondiscrimination Act would make it illegal for health insurers to deny coverage or increase premium prices for healthy people solely on the basis of a genetic predisposition to a specific disease. It would also stop employers from using such information in making decisions about hiring, firing or promotion.

In the past, Republican House leaders have not brought the bill to a vote. But with Democrats now in charge in both houses, where the bill has bipartisan support, it looks bound for passage into law after its introduction this January. President Bush put his voice behind a ban on genetic discrimination during a visit to the National Institutes of Health earlier in the month.

\section{Britain calls time on plan to advance clocks}

A plan to bring Britain's clocks into line with those in Europe failed to gather the necessary political support and so will be dropped.

The potential change, championed by supporters as a way to save lives and energy, would have given Britain an extra hour of evening daylight all year round, by advancing the clocks by an hour from their current times. Preliminary calculations suggest that the move could have saved around 100 lives a year through reducing traffic accidents in the evenings, and about $£ 485$ million (US\$950 million) in energy costs (see Nature 445, 344-345; 2007).

The private member's bill got marginal support in the 26 January vote, but failed to draw the necessary 100 Members of Parliament needed for the measure to proceed. Only 52 members voted, with 32 backing the bill.

\section{Bush offers words but no action on climate change}

President George W. Bush received some plaudits for referring to "the serious challenge of global climate change" in his State of the Union address last week. He called for a $20 \%$ drop in petrol use by 2017 , proposed raising fuel-efficiency standards for cars, and called for more research into alternative fuels - specifically boosting investment in finding new ways to produce ethanol as a biofuel. But he did not propose any limits on carbon emissions, leading many experts to say the speech was very light on actual commitments.

In the same week, researchers at the Massachusetts Institute of Technology in Cambridge called for a renewed focus on geothermal energy as part of the country's solution to weaning itself off oil. An investment of up to $\$ 1$ billion over 15 years, they said, could allow the United States to harness $10 \%$ of its electricity-generating capacity from the hot bowels of Earth by 2050. Geothermal energy currently accounts for less than $1 \%$ of US electricity use.

\section{Correction}

In our News story "PR's 'pit bull' takes on open access" (Nature 445, 347; 2007), we incorrectly quoted Wiley's director of corporate communications, Susan Spilka, as writing in an e-mail: "Media massaging is not the same as intellectual debate." She actually wrote "messaging", not "massaging". 